\title{
The Understanding of Local Cultural Treasures on Foreign Students in Indonesian Language Learning
}

\author{
Andayani $^{1, *}$, Lalita Gilang ${ }^{2}$ \\ ${ }^{1}$ Department of Indonesian Language Education, Universitas Sebelas Maret, Indonesia \\ ${ }^{2}$ Department of Visual Communication Design, Universitas Sebelas Maret, Indonesia
}

Received May 30, 2020; Revised July 6, 2020; Accepted August 10, 2020

\begin{abstract}
Cite This Paper in the following Citation Styles
(a): [1] Andayani, Lalita Gilang, "The Understanding of Local Cultural Treasures on Foreign Students in Indonesian Language Learning," Universal Journal of Educational Research, Vol. 8, No. 9, pp. 4113-4121, 2020. DOI: 10.13189/ujer.2020.080937.
\end{abstract}

(b): Andayani, Lalita Gilang (2020). The Understanding of Local Cultural Treasures on Foreign Students in Indonesian Language Learning. Universal Journal of Educational Research, 8(9), 4113-4121. DOI: 10.13189/ujer.2020.080937.

Copyright $\odot 2020$ by authors, all rights reserved. Authors agree that this article remains permanently open access under the terms of the Creative Commons Attribution License 4.0 International License

\begin{abstract}
The role of broad language may be implied in the increased role of the nation. The implications also can be seen in the role of the Indonesian language in the international area. This phenomenon is evidenced by the approval of that Indonesian language becomes subjects at 200 universities in ASEAN. However, there are some problems faced by foreign students studying in Indonesia. The problems commonly are issues related to cultural differences. These issues become an obstacle for foreign students studying in Indonesia. This research was conducted using a case study and qualitative approaches. The informants were foreign students who were studying the Indonesian language in Surakarta. The research results found that lack of the understanding of foreign students to the culture obstructs to the Indonesian language skills. The differences in the cultural background between the countries of origin of foreign students to the culture that exists in Surakarta make foreign students adjust the process of cultural adaptation. The adaptation was performed using the approach of familiarity and proximity.
\end{abstract}

Keywords Local Cultural, Indonesian Language Learning

\section{Introduction}

A language well known to the world can improve the role of the country where the language belongs (Gustav, 2015). This phenomenon has been occurring to the
Indonesian Language. The role of the Indonesian language as a mean of communication has been sought and approved since the Indonesian Language Congress IX (2008). The convention declared that Indonesian language functions as a medium of diplomacy in building Indonesian image in International level.

In the 32nd ASEAN Inter-Parliamentary Assembly (AIPA) in Cambodia (2011), Indonesian delegation proposed the mission to establish the Indonesian language as the official ASEAN language, particularly in AIPA assembly. This mission generated an agreement among the delegations. This is proven by the convention of the 33rd AIPA assembly in Bali (2012) which resulted in approval to the proposal that the Indonesian language will become a lecture subject in 200 universities in ASEAN.

The deal was then followed by the trial of Indonesian language lecture model in ASEAN territory. This model trial was conducted by sending Indonesian language lecturers to several countries such as Thailand, India, Philippine, Korea, China, and Japan. The trial model of Indonesian language lecture subject was conducted through Dharma Siswa Project of the Republic of Indonesia.

The model trial which had been conducted since 2012 found that the students in several countries were suggested their will to be introduced to the body of Indonesian culture (Andayani, 2015). Another impact of the lecturers visits ASEAN countries to conduct the Indonesian language model trial as a lecture subject is the increasing interest of the students to study in Indonesian Universities.

The increasing interest to learn the Indonesian language 
is also proven by the existence of 174 Indonesian language learning centres in 45 countries. Most of them are located in Japan, spreading at 38 learning centres. And in Australia, there are 36 learning centres (Maulipaksi, 2015). Higher interest rate to learn the Indonesian language means higher acknowledgement from other countries toward Indonesian identity as a nation. Thus, regarding the challenge faced by the Indonesian language in ASEAN Economic Community (AEC) since 2015, Indonesia does not need to be worried even though English has been determined as the official language of AEC. The Indonesian language still holds its position in the international language environment. Nevertheless, there is a problem faced by foreign students who learn the Indonesian language in Indonesia. The problem faced by the students is related to cultural difference issue. This problem has been an obstacle for foreign students learning the Indonesian language in Indonesia. Thus, this research aims to describe and explain the understanding of foreign students to the culture of Indonesia, describe and explain differences in cultural background between the countries of origin of foreign students to the cultures in Indonesia, which makes foreign students undergo a process of adaptation, and describe and explain the approach used to perform the adaptation process.

\section{Theoretical Review}

\subsection{The Local Cultural Treasures}

Local culture is described by Himstreet, Batty, and Murlin (2010) as the collective programming of a society performed at thought and action. These thoughts and actions differentiate these community members from other community members. In this case, it can be said that local culture is the collective programming of a community that describes a process. This process happens to everyone who has been a member of the community since that person was born. Furthermore, it was also explained that local culture is the local values of the work of the people in an area that are formed naturally and are obtained through the process of learning from time to time. Local culture can be in the form of art, tradition, mindset, or customary law (Lehman, Batty, and Himstreet, 2012).

Another opinion was explained by Ajawaila (2013) that local culture is a cultural characteristic of a local or regional community group. Local culture can also mean a set of values and rules that can be applied as beliefs, standards of behaviour, knowledge of local myths, and legal morals that have been trusted by the community. These values and rules determine how one person acts and others (Fox \& Diaz, 2016).

As the cultural treasures are the local cultural wealth possessed by certain areas, Cultural elements which become the featured product of the local culture are required in language teaching (Shin; Zohreh; Chen, 2011: 253-268). The cultural treasures importance can be manifested in the form of books or teaching materials (Solé, 2013: 141-150). This local culture refers to a certain culture which has implications on the target language taught. Further, in textbooks which also teach local culture, the priority is to introduce the culture first before introducing the language. If language teaching does not relate to the local culture, it will hinder the language learners. Meanwhile, the sociological values needed in the local culture is more than a cultural aesthetic aspect. The aspects in local culture are in the form of local community customs, local community belief system, and item products made by the local people (Najar, 2019: 148).

Local culture was explained by Koentjaraningrat (2005), as a system which grows and develops and is owned and recognized by the local ethnic group. Local culture usually grows and develops in a certain ethnic or geographical group due to the preserved heritage of the older generation. This local culture will occur when the people in a certain area have a similar mindset and social life so that they become a custom which differentiates the people from other groups of people.

Local culture seemed to be developing during the old royal era. This can be seen from the different lifestyle and social interaction done by the people in each kingdom in Indonesia. Each ethnic group in Indonesian territory has its own distinctive culture from one group to the others. Indonesia is one of the wealthiest countries in term of local culture because it has 200 to 250 ethnic groups with its diverse culture (Koentjaraningrat, 2005).

Local culture is defined as the original culture of a certain community. Brauchler (2015) explained that local culture is the cultural identity of the local community. But it is not easy to formulate or define the concept of local culture. The definition of culture is almost always bound to distinct physical and geographical boundaries. Accordingly, the geographical boundary has been used as the basis to formulate the definition of local culture. However, within the process of socio-cultural shift, there has been a tendency of the fading physical boundaries of culture. This is influenced by the accelerated migration and distribution factor of communication media at the global level so that there is not any an exclusively authentic local culture.

\subsection{The Local Culture Treasures Understanding}

The local culture treasures understanding is the requirement for someone to be able to socialize with the local community (Mora, Trejo, \& Roux, 2019: 182-198). Indonesian local culture treasures understanding is needed by people socializing in Indonesia. Regarding this matter, Geertz (1981) explained that in Indonesia, there are more than 300 ethnic groups who speak 250 different languages and have different local cultural characteristics. This 
phenomenon is important to understand. Besides, Indonesian territory has a different climate and geographic conditions. The different climate and geographical conditions influence the diversity of Indonesian local culture. The phenomena are important in giving understanding about Indonesian cultural treasures.

Cultural treasures understanding which someone has can be categorized into 3 categories, including translation understanding, interpretation understanding, and measurement understanding (Adler, 1991). Cultural treasures understanding which is included in the translation category is understanding in the literal meaning, bear meaning and implement principles existing in the cultural treasures. The interpretation category of the cultural treasures can be seen from someone's understanding in connecting the most simple parts with the later known parts or connecting several parts of events with the following events, distinguishing the primary elements from secondary elements in the cultural treasures (Salzmann, Stanlaw, \&Nobukoadachi, 2012). The measurement category of the cultural treasures understanding means to be able to see beyond what is written, to be able to make estimation and prediction according to the understanding and condition which are explained in ideas or symbols and to be able to make a decision which is related to its implication and consequence.

In line with the statement above, Ellis (2015) stated that cultural treasures can be classified into three aspects, namely translation, interpretation, and extrapolation. The meaning of translation here is not only the transfer of a message from one language to another language but also from the abstract conception to a model, a symbolic model which makes it easier for people to learn. The transfer of words formulated concept into graphics can be included in the translation category of the cultural treasures.

The interpretation category of the local culture body understanding is the ability to understand in a broader sense; ability to understand the main idea of the local culture body. And the extrapolation category of the local culture body is a higher form of understanding. This category demands a higher intellectual ability.

Providing an understanding of Indonesian local culture to people who are learning Indonesian is important. Understanding of local culture is not only limited to understand cultural outcomes in the forms of artefacts, but also cultural values of behaviour (Koentjaraningrat, 2009). These cultural values of behaviour are experiences for people who come to Indonesia both to study and to work. This must be realized by everyone who wants to live in Indonesia and join in the lives of Indonesian people.

Knowledge of noble values for people who learn a language can change the understanding of local culture and awareness of the benefits of knowing local culture (Jourdan \& Tuite, 2016). This can lead him to carry out various activities that are part of the local culture. Thus the understanding of local culture can enrich people's lives. It is said so because an understanding of local culture can provide profound experiences and make interactions between community members more harmonious, and intimate. The positive impact on people's lives is that it can make them happier when learning languages.

\subsection{Local Culture in Language Learning}

Local culture is an urgent element in learning a language (Atkinson \& Holmes, 2019:199-215), expressing the research finding that the gap in local culture understanding, of the students learning the Irish language, is linked to the positive attitude and the low level of courage in using the language. Students who understand the local culture well show better and more holistic understanding than the students who do not understand the local culture. Local culture understanding also supports a positive attitude during the students' language learning process.

Language and culture are tightly related. Language is the mean of cultural expressions. There is not a single knowledge of a cultural product which is delivered efficiently except through language medium (Prodromou, 2012: 39-50). Thus, language is the absolute supporting element of all of the human knowledge. With language, a nation's culture can be delivered all over the world, preserved, and passed down from generation to generations. Accordingly, a language system and discourse cannot be separated from the values and the cultural treasures, its matrix.

Meanwhile, Williams (2013) explained that language and culture are related and classified into three categories; that a language used by the community is a reflection of their whole culture; that language is a part of a culture of one of the culture's elements; that language is a condition of culture. That language is a condition of culture can mean two things. The first is that language is a condition of culture in a diachronic term, in which language precedes culture. It is through language that people become a civilized and cultured social being. The second is that language is a condition for culture due to the materials used in building a language are the same materials used in building culture. It means that language is the foundation for the establishment of various complex structures which is parallel with the other cultural elements (Peeters, 2015: 133-141).

Learning a language means learning to implement the language in use or "the manner of speaking a language." Speaking a language shows how a community or a nation carries out its culture. Speaking a language and carrying out a culture show a reciprocal relationship. To maintain a culture, a language is a prevalence. Consequently, to maintain a language, culture preservation is very important even though culture is human nature as a social being. Therefore, local culture becomes the main component for people who are learning a language.

The relationship between language and culture is 
subordinative. It means that language is under the scope of culture. Besides, there is another opinion which states that local language and culture have a coordinative relationship, namely an equal relationship, whose position is the same (Kramsch, 2012). He argues that a local language and culture are two systems that are "attached" to humans. Local culture is a system that regulates human interaction in society, so language is a system that functions as a tool in the local community.

Kramsch, (2012) also questioned how the relationship between local language and culture, whether subordinative or coordinative. If it is subordinative, which one is the main system (superior system) and which one is the subsystem (subordinate system). Most experts do say that culture is the main system, whereas language is only a subsystem.

Regarding the coordinative relationship between local language and culture, there are two things, namely the relationship between the two like twins. This is also the same as two phenomena that are tightly bound like the relationship of one side to the other side of a coin (Salzmann, Stanlaw, \& Nobukoadachi, 2012). So, this opinion says that local language and culture are two different phenomena, but the relationship is so close that it cannot be separated.

An interesting point in the relationship between language and local culture is the existence of a controversial hypothesis, the hypothesis of linguists Edward Sapir and Benjamin Lee Whorf. This hypothesis is known as the Sapir and Whorf hypothesis. Although the ideas they put forward are the results of long and in-depth research and are presented in essays with very high scientific weight their ideas are mentioned in their very controversial hypotheses (Bennardo, 2009).

In that hypothesis, it was stated that language not only determines the state of local culture but also determines the ways and ways of thinking of humans. In a nation whose language is different from other nations, its people will have a pattern of local culture and a different way of thinking. The differences in local culture and the way of human thought are sourced from differences in language. Language influences human culture and way of thinking, so the characteristics that exist in a language will be reflected in the attitudes and the culture of the speaker.

\section{Methodology}

\subsection{Foreign Speaker Context of Indonesian Language Learners}

This study involved the foreign speakers currently learning the Indonesian language at Sebelas Maret University, Surakarta, Central Java, Indonesia. There are two groups of these learners; lower-level cognitive skills and higher-level cognitive skills. Foreign learners who are included in lower-level cognitive skills need learning materials which emphasize the form of identification while the learners included in higher-level cognitive skills need learning materials which emphasize meaning interpretation. For lower-level cognitive skills learners, who are usually at the beginner class, the use of learning materials which emphasize the forms is very important to bridge the communication gap between teacher and learner. It can be imagined what might happen in the class if the learners do not understand a single word of the language that they are learning while the teacher must deliver the material using the language that he is teaching.

The research data collection was conducted from February to August 2019. The time was selected by considering the effective schedule of Indonesian language training for foreign students at Sebelas Maret University, Surakarta, Central Java, Indonesia.

\subsection{Research Questions}

Referring to the aforementioned issues, this study formulates three research questions to find the data concerning the understanding of local cultural treasures on foreign students in Indonesian language learning as follows.

(1) How is the understanding of the foreign students joining in Indonesian language training toward Indonesian local culture?

(2) What are the differences between the cultural background of the students learning the Indonesian language's origin country and Indonesian local culture?

(3) How is the adaptation process is done by the foreign students, members of Indonesian language training, in understanding Indonesian local culture?

\subsection{Research Approach}

This research was conducted by using the Case Study Qualitative Approach. The case study method is chosen by considering that the research focuses on a single case. It means that the studied case focuses on the understanding of foreign student joinning Indonesian language training toward the local culture, therefore, this research uses single case study. This is in accordance to Campbell's explanation (2005: 178-193); Hamilton (2008: 76-92); and Yin (2002: 122), Berg (2004: 251), that case study is a method which can be used to study complex problem. This research involves various sources of data, that may produce a large number of data to be analyzed.

\subsection{Research Data Collection}

Research data collection was conducted through In-depth Interview (Leech, 2007; Miles \& Huberman, 2012; Ryan \& Bernard, 2012). The reason for using this technique is due to its accuracy as the data collection technique. In this research, the researcher found the problems and in-depth information from the informants who were involved in this study. The interview was 
conducted in this research by asking structured questions because the researcher used systematically arranged interview guidelines to collect the desired data. The interview in this research was conducted to foreign students who learnt the Indonesian language at Sebelas Maret University.

Table 1. List of Foreign Student Informants Participants of Indonesian Language Training

\begin{tabular}{cccc}
\hline No & Name & Country of Origin & L-1 \\
\hline 1 & L M & Cambodia & Khmer \\
2 & SAL & Madagascar & Malagasy \\
3 & WYS & Myanmar & Burmese \\
4 & Thu & Thailand & Thai \\
5 & TBr & Australia & English \\
6 & LKK & Greece & English \\
7 & RLe & USA & English \\
8 & MMA & Serbia & Slavic \\
9 & BBA & Uzbekistan & Uzbek \\
10 & SDA & Turkey & Turkish \\
\hline
\end{tabular}

The informants were foreign students from various countries with first language origin (L-1) English and students with first language origin (L-1) non-English. They were purposively selected to achieve complete data. All of them came from different countries. List of the informants can be seen at Table 1 .

The data collected from an in-depth interview with 10 students were validated by implementing internal validity (Seliger \& Shohamy, 2012: 95) and by using the triangulation technique. The triangulation technique referred to accurate research findings which reflect the situation and are supported with evidence. It also referred to the research consistency in data collection and analysis regarding data validation (Patton, 2001:277) and Miles \& Huberman (2012: 271) who argued how triangulation works concretely and in a good way.

In the data triangulation, various kinds of data source and evidence of different situation were used. There are 3 sub-kinds of sources people, time, and space. The data source of people means that the data were collected from people doing the same activity. The data source of time means that the data were collected at different times. And data source of space means that the data were collected in different places. This form of triangulation has a complex character. It means that it combines several sub-type or all levels of analysis. If the data are consistent, then validity has been established. The application of triangulation theory technique in this research is conducted by employing various theoretical perspectives to interpret a group of data.

The technique of analysis employed is Interactive Technique (Leech, 2007; Miles \& Huberman, 2012; Ryan $\&$ Bernard, 2012). Activities in qualitative data analysis were conducted interactively and continuously up to the final stage so that the data were saturated. The data saturation level is indicated when there are not any new data or information found. The activities in the data analysis include data reduction, data display, conclusion and verification.

Data analysis was sought through data collection which is directly followed by recording, editing, classifying, reducing, and displaying, and then concluding. Steps of analysis refer to the following model from Miles and Hubermen (2012). Data reduction as the initial step of analysis is done by summarizing direct contact data of people, event, and situation in research location. The second step is data coding. The third step is the objective data recording. In this research informants' answers and situation were recorded, classified, and edited as they are, factually or descriptive-objectively. The fourth step of this research is making reflective records. The fifth step of this research is making marginal records. The sixth step is data storage. The seventh step is an exposition of idea according to the theory, which is also called an idea conceptualization and it is begun with opinion development or proposition. The eight steps are interlocation analysis since each informant is often in different locations. This usually happens in data collection and analysis in which the data sources are informants with L-1 English and informants with L-1 is non-English. The ninth step is the temporary summary of interlocation analysis. The next step is Data Display or Data Analysis after Data Collection. On this step, the previously collected and analyzed data are displayed, considering that a qualitative researcher does many narrative texts. The final step is verification and conclusion.

\section{Research Findings}

The research finds that foreign students' lack of understanding toward Indonesian culture for they held back their skills particularly in the spoken Indonesian language. The difference in cultural background between the foreign students' country of origin and Indonesian culture requires foreign students to go through the adaptation process. Further explanation can be found in the following argumentation.

\subsection{Foreign Students' Understanding toward Indonesian Local Culture}

Regarding the understanding of foreign students participating in Indonesian language training toward Indonesian local culture, the interview results show that during their stay in Indonesia, the students experienced culture shock due to the lack of understanding toward Indonesian culture. This condition is expressed by informants LL, TT, and LM.

LL expressed that, "When I first came to Indonesia and joined this university, I was surprised because the local students did not only speak in the Indonesian language, but they also spoke in different local languages. This was very confusing for me" (Fieldnote 0112). 
The use of local language in the learning environment of the foreign students becomes an obstacle in communication, but, this fact can also be an additional knowledge for the foreign students that in Indonesia, the people do not only speak Indonesian language, but they also speak local languages in daily conversation. Meanwhile, regarding the understanding of Indonesian culture, another foreign students informant TT who comes from Thailand expressed as follow:

"Indonesian culture is easy for me to follow. The culture which is similar to mine is politeness and being respectful to others. The first time I wanted to speak to the local student, is because I saw that they are kind people, modest, friendly, and my favourite is that they like to laugh a lot. The good thing about them is that when we don't understand each other in communication, they are not angry, they still give a friendly gesture or sometimes they just smile or laugh" (Fieldnote 0114).

From the informant above, it found that similarity in a culture like politeness is a supporting element for foreign students to understand Indonesian local culture. This is different from the local culture understanding expressed by $\mathrm{LM}$ as follows.

"My culture is different from my friends' culture in Indonesia. I communicate with my close local student friend in English because I'm not so fluent in speaking the Indonesian language. And only some parts of the Indonesian language which I understand" (Fieldnote 0216)

From the three informants, it found that not all of the foreign students had difficulty in understanding Indonesian local culture. One of the students found it easy to understand Indonesian culture because there is cultural similarity and that incomprehension can be overcome by them. Meanwhile, some informants found it difficult to understand the Indonesian local culture. This is expressed by TB, LKK, and RL (all of them speak English as L-1). They expressed it as follow.

"When local students want to communicate with me, they use English. Well ... it was like a little bit of English and a little bit of Indonesian language. But when I am in class, language is a problem for me because I don't understand. I don't understand the Javanese Language at all, and the Indonesian language, I only understand $45 \%$ of it" (Fieldnote 0221).

From the informants' explanation above, it can be seen that some foreign students whose L-1 is English found difficulty in understanding culture related to the use of Indonesian language. Regarding this matter, informants TB and LK expressed the following.

"In Indonesian culture, I was surprised when a lecturer reprimanded me because I addressed a professor with the word 'Кати' (you). It was said to be impolite and that I must address a lecturer with the word 'Bapak' or 'Ibu' (sir or madam)'(Fieldnote 0317).

The next finding of Indonesian local culture understanding about politeness in using the Indonesian language was found from informants $\mathrm{SD}$ and $\mathrm{WY}$ as follow.

"There are many words in the Indonesian language which are considered to be impolite to be said in public such as the word "payudara" (breast). To say the word "payudara," someone must use the expression "Maaf (sorry), payudara." Or "Maaf, pantat. (ass)" We, foreign students, once asked the lecturer "Why has it to be that way?", the lecturer answered, "Well, this is the way in Indonesian culture" (Fieldnote 0409).

Foreign students understanding of Indonesian culture is varied. The foreign students understanding of Indonesian culture in the form of objects has generally been established. Almost all of the informants declared to have understood Indonesian local culture in terms of artefacts. There is another finding regarding the way how foreign students participating in Indonesian language training understand the cultural treasures. This finding was expressed by informant SAL as to the following.

"I am glad to join the dance practice because I can compare the dance from Madagascar with Indonesian local dance and that I can get more friends. (Filednote 0511).

Another data explained the way foreign students participating in Indonesian language training in understanding the local culture. The interview result data with informants WYS and SD expressed the following.

“...getting to know Indonesian local traditional games such as kelereng (marbles), makan kerupuk (cracker eating race), congklak, and kasti (traditional baseball game). I knew those games from the neighbourhood around the place where I stay in Solo.". (Fieldnote 0621).

From the data expressed by informants Sal, WYS, and $\mathrm{SD}$, it can be seen that learning the local culture helps the students understand and adapt to the Indonesian language. Introduction to Indonesian local culture for foreign students is done by interacting with the Indonesian community both in the university area and in the neighbourhood where they stay. Another finding of this research is the different cultural background of foreign students.

\subsection{Communication Pattern in Different Cultural Background}

Communication patterns in speaking Indonesian related to different cultural background between the foreign students' country of origin and the culture in Indonesia are 
found in this research as expressed by informants LM, LK.BB, and SD, as in the following expression.

"As expressed by LM and SD, I first got to know local students during the general lecture subject, I was acquainted with many students since I am a sociable person. Here, I have many local student friends in many faculties. I always hang out with them, eat with them, or go on a picnic such as to the beach with them. I do those activities to understand the difference between my culture and Indonesian local culture" (Fieldnote-0703).

"Informants $L K$ and $B B$ expressed the following; the first time I communicated with other foreign students from other different countries during joint research, cultural performance, and outbound training." (Fielnote-0704)

According to results of the interview, it found that the communication pattern between foreign students with different cultural background and the local students is as follow; firstly, the foreign students conducted research before they go to Indonesia, then, on their early stay in Indonesia, they experience cultural shock, then they ask for suggestions to their fellow foreign students about the way to adapt the local culture in the country new to them. And finally, intensely interacting and communicating with the local students, the foreign students eventually achieve cultural understanding. Inter-cultural communication pattern between foreign students and local students is done through several stages of the approach, from the early interaction phase to the friendship stage. There are several stages of communication pattern according to the research conducted on the informants.

\subsection{The Adaptation to Understand the Cultural Treasures and Indonesian Language}

In this research, it found that the foreign students adapted to understand Indonesian local culture. Various adaptation efforts are done to understand the Indonesian language better. Regarding this matter, informants MM and LKK explained as follows.

"Besides using verbal communication, I sometimes use nonverbal communication when I don't understand what I should say, for example, I shake my head or my hand when I refuse something." (Fieldnote-0910).

The communication characteristics in the Indonesian language experienced by the foreign students are generally dynamic, non-formal, and continuous due to the sense of having a similar experience, meanwhile, the communication characteristics which happens between local students and foreign students are signified with the high level of awareness and formal dialogues, and with more frequent occurrence of misunderstanding in the message perception. And as experienced by LKK, this
Greek student tries to avoid misunderstanding by using hand gestures so that the local students can understand what he meant. LKK's expression is as follow.

"If the local students do not understand the language that I use, I usually use non-verbal communication such as hand gestures so that they understand what I am saying." (Fieldnote-0921).

During the communication process among students with a different culture, signs language are of concern to be identified. Non-verbal message emphasis on the verbal message can complement and enrich the message so that it can be interpreted easier between the message carrier to the message receiver. Thus, it is through the body of culture, people learn to communicate properly in using the Indonesian language.

Even though foreign students still find difficulty in understanding the language spoken by the local students such as Javanese language, it is not of concern since the foreign students are willing to keep learning until they understand it. Campus environment and even outside of the campus environment are the places for foreign students to mingle and socialize with the local students.

\section{Discussion}

Foreign students understanding of Indonesian culture is varied. The variety of understanding is caused by mainly the students' lack of understanding in term of sosiofak. Sosiofak is related to social behaviour and real-life behaviour application (Jaime \& Rios, 2006: 37-55). Social behaviour is the main obstacle for students who study overseas. According to Thurstone, Likert, and Osgood (in Timmermans, Boer, \& Werf, 2019: 217-240), such social behaviour is an evaluation or reaction of feeling. This feeling reaction is represented as the habitual application of Indonesian people's social behaviour. This is what the foreign students who study in Indonesia need. What occurs within the research setting is that some of the foreign students were favourable toward the social behaviour of Indonesian culture, and some of them were unfavourable to it.

This finding is in line with what Brown and Yule's statement (2013: 1) which says that language is not merely a communication device. Moreover, a language in its use is a part of the message in communicating. In communicating using local language, there is a local culture which must be implemented. This is what Brown and Yule described the term 'transactional' and 'interpersonal.' It means that there are customs and culture in using a language as meaningful communication.

Things related to the adaptation process with the local culture are important for foreign students in Indonesia to learn the Indonesian language. What occurs during the adaptation process is the communication process. The 
communication process is a part of a communication pattern which is done by someone in his/her daily activity to interact with other people who have a different culture.

Students' motivation to adapt local culture depends on the number of students' opportunity to get to know the local culture. According to Berger and Leukman (in Gudykunst and Kim, 2012:90), socialization and enculturation are the basic forms of basic human behaviour expression which are internalized to study the characteristics of the local culture surrounding the language being learned.

To be able to overcome the obstacle, the solution done is building positive interaction with the local people (Porter \& Samovar, 2010: 206-210) or building empathy or sympathy toward the local culture. This is often called as familiarity. It means that foreign students adaptation in learning the Indonesian language is done by doing familiarity with the local culture. Some forms of the familiarity activities which support the skill of speaking in the Indonesian language are familiarity night program with the local students and outbound program for an Indonesian language class. Informally, foreign students can also communicate directly with the local people. They often use gesture to deliver a message for some things that they do not understand.

Another adaptation done is the proximity approach which means the effort to realize closeness (Fox, Diaz, \& Greenberg, 2016). Proximity is manifested in forms of clothing and fashion, the foreign students choose to be open-minded and try to be familiar with the culture in Indonesia. This also happens in term of food preference. The foreign students try to adapt to the food in Indonesia, even though they find it difficult at first, eventually they can adapt so that they prefer to keep consuming the local food. An interest in food makes them happy to be in Indonesia, and in the end, they can be more eager to learn Indonesian. Finally, foreign students can be adaptive and skilled in using the Indonesian language.

\section{Conclusions and Suggestions}

The conclusions of this research are (1) Besides language difference, foreign students find difficulty in understanding the cultural treasures because Solonese people often use bilingual language when communicating with the foreign students; (2) The stereotype which occurs in Indonesia shows that there are limitations for foreign students to communicate with Solonese freely. This limitation has created a distance in communication and even may lead to negative prejudice; (3) Foreign students who learn the Indonesian language try to think like the local community (familiarity) and put efforts to approach the society (proximity). Those are the ways that are usually done by foreign students to adapt and to understand the cultural treasures.

Regarding the results of this research, some suggestions can be proposed as (1) Foreign students are individuals who try to adapt to the new environment where they live in, therefore, the local students should participate in helping them to go through the adaptation process; (2). An open mindset is really important for foreign students to help them to adapt; (3) Adaptation is not merely an issue for the party doing the adaptation only, the participation of the local community is also very important to achieve communication equality and effectivity in using the Indonesian language.

\section{Acknowledgments}

We are very grateful to experts for their appropriate and constructive suggestions to improve this template.

\section{REFERENCES}

[1] Adler, N.J. (1991). International Dimensions of Organizational Behavior. Boston, MA.: PWS-Kent Publishing Company.

[2] Andayani \& Gilang. (2015). The Effectiveness of Integrative Learning-Based Textbook toward the Local Culture for Foreign Students. International Journal of Humanities and Social Science. V (1): 197.

[3] Atkinson, D. \& Holmes, H.K. (2019). Exploring language attitudes and ideologies in university students' discussion of Irish in a context of increasing linguistic diversity. Language and Intercultural Communication. XVI (2):199-215

[4] Bennardo, Giovanni. (2009). Language, Space, and Social Relationships A Foundational Cultural Model. New York: Cambridge University Press.

[5] Brauchler, B. (2015). The Cultural Dimension of Peace Decentralization and Reconciliation in Indonesia. New York: St. Martin's Press LLC.

[6] Berg, B.L. (2004). Qualitative Research Methods for the Social Sciences. New York: Pearson Publishing

[7] Brown, G. \& Yule, G. (2013). Discourse Analysis. Cambridge University Press.

[8] Campbell, D.T. (2005). Assessing the Impact of Planned Social Change. Hungary: The Public Affairs Center, Dartmouth College.

[9] Ellis, Rod. (2015). Understanding Second Language Acquisition. Oxford: Oxford University Press.

[10] Fox, R., \& Diaz, Greenberg, R. (2016). Culture, Multiculturalism, and Foreign Language Standards in U.S. Teacher Preparation Programs: Toward a discourse of dissonance. European Journal of Teacher Education, XXIX (3), 401-422.

[11] Geerzt, H. (1981). Aneka Budaya dan Komunitas di Indonesia. Jakarta: UI Press.

[12] Gudykunst and Kim, (2012). The influence of language on uncertainty reduction: An exploratory study of 
Japanese-Japanese and Japanese-North American interactions. Communication Yearbook. IX (1):90.

[13] Gustav, H. (2015). The Advanced Theory of Language as Choice and Chance. London: Macmillan Science Communication Publ.

[14] Hamilton. (2008). Education Research: Principles, Policies and Practices. London: Routledge.

[15] Himstreet, William C; Baty, Wayne Murlin. (2010). Culture Business and Communications: Principles and Methods. Boston: PWSKent Publishing Company.

[16] Jaime, A \& Rios, F. A. (2006). Native American Faculty and Student Perspective. Taboo: The Journal of Culture and Education. X (2):37-55.

[17] Jourdan, Christine \& Tuite, Kevin. (2016). Language, Culture, and Society. Key Topics in Linguistic Anthropology. New York: Cambridge University Press.

[18] Koentjaraningrat. (2005). Kebudayaan Mentalitas dan Pembangunan. Jakarta: Penerbit PT. Gramedia.

[19] Koentjaraninggrat. (2009). Ilmu Antropologi. Jakarta: Renaka Cipta.

[20] Kramsch, Claire. (2012). Language and Culture. Oxford University Press.

[21] Leech, G. (2007). Principles of Pragmatics. London: Longman.

[22] Lehman, Carol M; Himstreet, William C; Baty Wayne Murlin. (2012). Local Culture Business Communications. 11 Edition. Ohio: South-Western College Publishing.

[23] Maulipaksi, D. (2015). http://www.kemdikbud.go.id

[24] Mora, A.; Trejo, P.; Roux, R. (2019). The complexities of being and becoming language teachers: issues of identity and investment. Language and Intercultural Communication. XVI. (2):182-198.

[25] Najar, U. (2019). The 'intercultural field': interrogating context in intercultural education. Language and Intercultural Communication.XVI. (2): 148-163.

[26] Miles, M.B. \& Huberman, A.M. (2012). Qualitative Data Analysis: An Expanded Sourcebook. London: SAGE Publications, Inc.
[27] Patton, M.Q. (2015). Qualitative Research \& Evaluation Methods: Integrating Theory and Practice. London: SAGE Publications, Inc.

[28] Peeters, Bert. (2015). Language and culture values: adventures in applied ethnolinguistics. International Journal of Language and Culture. II. (2): 133-141.

[29] Porter, RE; Samovar, L.A; \& McDaniel, ER. (2010). Communication Between Cultural. Boston: Wadsworth Publ.

[30] Prodromou, Luke. (2012). What culture? Which culture? Cross-cultural factors in language learning. English Language Teaching. LXVI. (1): 39-50.

[31] Ryan, G.W. \& Bernard, L. (2012). Measuring the typicality of text: Using multiple coders for more than just reliability and validity checks. London: SAGE Publications, Inc.

[32] Salzmann, Z; Stanlaw, M; Nobukoadachi. (2012). Language, Culture, and Society. Philadelphia: Westview Press.

[33] Seliger, H.W. \& Shohamy, E. G. (2012). Second language research method. Oxford: Oxford University Press.

[34] Shin, J; Zohreh, R. E; Chen, W.C. (2011). Presentation of local and international culture in current international English-language teaching textbooks. Language, Culture and Curriculum. XXIV(3): 253-268.

[35] Solé, C.R. (2013). Culture for Beginners: A Subjective and Realistic Approach for Adult Language Learners. Language and Intercultural Communication. III (2): 141-150.

[36] Timmermans, A.C.; Boer, H.D, \& Werf, M.P.C. (2019). An investigation of the relationship between teachers' expectations and teachers' perceptions of student attributes. Social Psychological Education. XIX (2) :217-240

[37] Wilson, R \& Dissayanayake, W. (2012). Global Local Cultural Production and The Transnational Imaginary. London: Duke University Press.

[38] Williams, R. (2013). Keywords: A vocabulary of Culture and Society. London: Flamingo Publ.

[39] Yin, R.K. (2013). Case Study Research (International Student Edition): Design and Methods. London: SAGE Publications, Inc. 